\title{
Correction to: A Response to the Letter to the Editor Regarding "Nationwide Prevalence of Diabetes and Prediabetes and Associated Risk Factors Among Iranian Adults: Analysis of Data from PERSIAN Cohort Study"
}

Mohammad E. Khamseh · Sadaf G. Sepanlou · Reza Malekzadeh (D)

Accepted: December 15, 2021 / Published online: January 16, 2022

(C) The Author(s) 2022

Correction to: Diabetes Ther

https://doi.org/10.1007/s13300-021-01187-8

The original version was published with an incorrect article title. The correct article title is "A Response to the Letter to the Editor Regarding "Nationwide Prevalence of Diabetes and Prediabetes and Associated Risk Factors Among Iranian Adults: Analysis of Data from PERSIAN Cohort Study".

The original article can be found online at https://doi. org/10.1007/s13300-021-01187-8.

M. E. Khamseh

Endocrine Research Center, Institute of

Endocrinology and Metabolism, Iran University of

Medical Sciences (IUMS), Tehran, Iran

S. G. Sepanlou

Digestive Disease Research Center, Digestive

Diseases Research Institute, Tehran University of

Medical Sciences, Tehran, Iran

R. Malekzadeh $(\bowtie)$

Digestive Oncology Research Center, Digestive

Diseases Research Institute, Tehran University of

Medical Sciences, N. Karegar Ave. Shariati Hospital,

14117-13014 Tehran, Iran

e-mail: malek@tums.ac.ir;

dr.reza.malekzadeh@gmail.com
Open Access. This article is licensed under a Creative Commons Attribution-NonCommercial 4.0 International License, which permits any non-commercial use, sharing, adaptation, distribution and reproduction in any medium or format, as long as you give appropriate credit to the original author(s) and the source, provide a link to the Creative Commons licence, and indicate if changes were made. The images or other third party material in this article are included in the article's Creative Commons licence, unless indicated otherwise in a credit line to the material. If material is not included in the article's Creative Commons licence and your intended use is not permitted by statutory regulation or exceeds the permitted use, you will need to obtain permission directly from the copyright holder. To view a copy of this licence, visit http:// creativecommons.org/licenses/by-nc/4.0/. 